\title{
Typification of Solanum (Solanaceae) species described by Martín de Sessé y Lacasta and José Mariano Mociño
}

\author{
by \\ Sandra Knapp \\ Department of Botany, The Natural History Museum, Cromwell Road, London SW7 5BD, United Kingdom. s.knapp@nhm.ac.uk
}

\begin{abstract}
Knapp, S. 2008. Typification of Solanum (Solanaceae) species described by Martín de Sessé y Lacasta and José Mariano Mociño. Anales Jard. Bot. Madrid 65(1): 7-23.

Lectotypes, neotypes or epitypes are confirmed or designated here for 16 of the 22 names coined by Martín Sessé y Lacasta and José Mariano Mociño that were described as members of the large genus Solanum (Solanaceae): Solanum bifidum, S. cordovense, S. declinatum, S. dichotomum, S. diphyllum, S. lanceifolium, S. lanceolatum, S. lineatum (both homonyms), S. longifolium, S. mexicanum, S. nutans, S. sarmentosum, S. scandens, S. tlacotalpense and S. uniflorum. A brief introduction assesses the importance of the Sessé \& Mociño expedition (the Real Expedición Botánica a Nueva España) to the botany of their time, and identifies difficulties in identifying and neotypifying or lectotypifying names coined by them. More than half of the names coined by Sessé and Mociño have no material associated with them. The currently accepted name for each taxon is given, and taxa of uncertain status are indicated. Each typification is accompanied by a discussion of the reasoning behind the choice of specimen, and all newly designated types are illustrated.
\end{abstract}

Keywords: typification, historic collections, exploration, Mexico, Central America.

\section{Introduction}

The $18^{\text {th }}$ century expeditions to the New World financed by the Spanish Crown greatly increased scientific knowledge of the flora of the Americas, as these great journeys traversed lands previously only visited by observers, not collectors, and thus subsequently brought back to Spain many new plants, both as herbarium specimens and as seeds that were grown out and the plants brought into cultivation. Solanaceae featured prominently in these novelties not only because the Americas are the centre of diversity at both the generic and specific ranks in the family (see

\section{Resumen}

Knapp, S. 2008. Tipificación de Solanum (Solanaceae), especie descrita por Martín de Sessé y Lacasta y José Mariano Mociño. Anales Jard. Bot. Madrid 65(1): 7-23 (en inglés).

Se confirman o designan los lectótipos, neótipos o epítipos de 16 de los 22 nombres acuñados por Martín de Sessé y Lacasta y José Mariano Mociño que o bien fueron descritos dentro del género Solanum (Solanaceae) o son actualmente reconocidos como parte del mismo): Solanum bifidum, S. cordovense, S. declinatum, S. dichotomum, S. diphyllum, S. lanceifolium, S. lanceolatum, S. lineatum (ambos homónimos), S. longifolium, S. mexicanum, S. nutans, S. sarmentosum, S. scandens, S. tlacotalpense y $S$. uniflorum. Se incluye una breve introducción explicando la importancia de la Real Expedición Botánica a Nueva España (expedición de Sessé y Mociño) para la botánica de su tiempo, así como las dificultades que entraña neotipificar o lectotipificar los nombres acuñados por éllos. Se incluye el nombre aceptado para cada taxon cuando es posible y cada tipificación se acompaña de una discusión explicando la elección de los especímenes. Todos los tipos nuevos se acompañan de una foto.

Palabras clave: tipificación, colecciones históricas, exploración, México, America Central.

Knapp, 2007a), but also because many Solanaceae are relatively weedy and easy to cultivate. Solanum L., with ca. 1500 species, is the largest genus in the Solanaceae and one of the ten most species-rich genera of flowering plants (Frodin, 2004). As part of the collaborative project "PBI Solanum: a world-wide treatment” (see Knapp \& al., 2004a; http://www. nhm.ac.uk/solanaceaesource), descriptions of all species of Solanum together with details of types and nomenclature are being provided via an on-line taxonomic resource, Solanaceae Source. One of the goals of the PBI Solanum project is to designate lectotypes for all Solanum names, helping to stabilise nomenclature 
and facilitate further taxonomic research. This paper is the second of a series (see Knapp, 2007b) on the nomenclature of Solanum in which lectotypes for the names described by a particular author or authors (rather than for a taxonomic section of Solanum) are designated.

The Real Expedición Botánica a Nueva España, better known to botanists as the Sessé and Mociño Expedition, lasted sixteen years (1787-1803), and throughout the "expedition" various combinations of members travelled as far from Mexico City as Vancouver (British Columbia, Canada) via California (Simpson, 1938, 1962) and south to El Salvador (Mociño, 1993; maps in Maldonado \& Puig-Samper, 2000). The original participants of the expedition were Martín de Sessé y Lacasta (director and botanist), Vicente Cervantes (botanist), José Longinos Martínez (naturalist/zoologist), Juan de Castillo and Jaime Senseve (both botanists); José Mariano Mociño and Juan Maldonado later became important members of the group. Full accounts of the personalities and events of the expedition can be found in McVaugh (1977), Maldonado (1997) and San Pío \& Puig Samper (2000).

The botanists of the expedition were up-to-date in the botany of their time; they prepared work for publication while they were in the New World, and once back in Spain in 1804 they began to compile a publication of their findings (Blanco, 2000). Sessé calculated that the expedition had collected some 3500 herbarium specimens of which 2500 species were new to science, as were almost 200 new genera and when he returned to Spain, the team had already prepared at least three manuscripts, all done in the Linnaean system, ready for publication (Blanco, 2000). Sadly, however, the funds necessary for the completion of the work dried up, at least in part due to the massive expenditures made by the Spanish government during the Napoleonic Wars. Sessé died in 1805, and Mociño left Spain for exile in France under a political cloud in 1812 (see Fuertes et al., 1999). Some of the new plants were described by Casimiro Gómez Ortega, Antonio José Cavanilles and Mariano Lagasca, and many of the herbarium specimens were sold to other herbaria in Europe by José Pavón, who was in charge of the Oficina Botánica where the specimens were held. Pavón began to sell off the office's assets due to financial difficulties after his botanical partner Hipolito Ruiz's death in 1816 (see Steele, 1964; Castroviejo, 1998). These specimens were labelled as coming from "Pavón" with no recognition of their original collectors or provenance. New species described from these specimens were often assumed to come from Peru, where Pavón himself had collected (McVaugh, 2000a). In addition to specimens, water- colour and pencil drawings were made (McVaugh, 1982; McVaugh, 2000b), and some new taxa were described from these by various authors. These drawings are today held in the archives of the Real Jardín Botánico of Madrid and in the Torner Collection of the Hunt Botanical Institute (McVaugh, 1982; Zamudio, 2000). Typification of names associated with these drawings is very complex; two of the Solanum names treated here have been so typified (see $S$. mexicanum and $S$. uniflorum).

Between 1887 and 1897 two of the manuscripts from the archives of the Real Jardín Botánico were edited and published in Mexico, with the authorship attributed to Sessé and Mociño (Sessé \& Mociño, 1888 , 1894). McVaugh $(1977,2000 a)$ considers the Flora Mexicana (1891-1897) to be a compilation of original field and other notes and the Plantae Novae Hispaniae (1887-1891), although published earlier, to be the edited version of these same notes. There is not necessarily a one-to-one correspondence of names or even concepts between the two works. Rickett (1947) and McVaugh $(1977,2000 a)$ have considered the second edition of Flora Mexicana, which was revised and reset, to have priority over the first edition from page 49 onwards; Solanum appears beginning on page 50 , so the second edition (1894) has priority for Solanum names. Many new names were proposed in both these works, but in the hundred years between their initial preparation in the late $18^{\text {th }}$ century and publication in the late $19^{\text {th }}$ century, many of the new taxa had already been described by others, so relatively few of Sessé and Mociño's names are accepted today (see below). McVaugh's (2000a) catalogue of the scientific names of the expedition is incredibly useful, and his notes were extensively used here. More recently, facsimile editions of the Caribbean (Blanco et al., 2000) and Central American (Mociño, 1993; Maldonado, 2006) manuscripts of the expedition have been published, but all new names in those fascimiles are not validly published under the current Code, so are of historic interest only (see Knapp \& Davidse, 2006).

The French botanist Michel-Félix Dunal worked with Agustin Pyramus de Candolle in both Montpellier and Geneva, and in his monographs of Solanum (Dunal, 1813, 1816), and in his treatments of Solanum for Poiret's Supplémente to Lamarck's Encyclopédie (Dunal, 1814) and de Candolle's Prodromus (Dunal, 1852) published many new Solanum names based on either drawings (originals and copies, depending upon the date of publication, see McVaugh, 2000b) from the Sessé and Mociño expedition (see above) or material he attributed to "Pavón in herb. Boiss." Many names based on herbarium specimens in G attributed to Pavón are really based on collections from 
the Sessé and Mociño expedition, and their provenance must be carefully checked against the duplicates of these sheets and manuscripts in MA. Table 1 lists these Solanum names; for details of their identity and typification see Solanaceae Source (http: //nhm.ac.uk/solanaceaesource).

In 1936 the entire Sessé and Mociño herbarium was sent to Dr. Paul C. Standley in the Field Museum in Chicago for naming. The specimens were loose in numbered folders; the numbers had been assigned by Dr. José Cuatrecasas apparently indicating an opinion that the sheets therein were somehow related (see McVaugh, 2000a). These numbers, although they are of- ten treated as such, are not collecting numbers, and sometimes different species in different genera bear the same "Madrid number" (McVaugh, 1990); these numbers are better cited as "Herb. Sessé \& Mociño" than as collecting numbers in the modern sense (McVaugh, 2000a). Before the return of the material to Madrid, each sheet was given a label (see lower right hand corner of the sheets in Figs. 1-4) and was photographed with the negative being assigned a number in a sequence between 41100 and 48937 (McVaugh, 2000a); these F negative numbers were the only unique references to these sheets until they were given herbarium numbers at MA. The photographs from

Table 1. Solanum names published by Michel-Félix Dunal based at least in part on either the drawings (those from 1814-1816) or specimens (in 1852) of the Sessé and Mociño expedition. Accepted names are in bold face type, for details of synonymy and typification please see data on Solanaceae Source (http://nhm.ac.uk/solanaceaesource) and in the text. In his catalogue of the relevant scientific names of plants of the Sessé and Mociño expedition, McVaugh (2000a) includes Solanum heterodoxum Dunal and S. pubigerum Dunal (both published in 1813), but neither of these names is based on Sessé and Mociño material although Dunal cited expedition material in his later treatments of these names.

\begin{tabular}{|c|c|}
\hline Species name & Publication \\
\hline Solanum anacanthum Dunal & in DC., Prodr. 13(1): 183. 1852. \\
\hline Solanum anoplocladum Dunal & in DC., Prodr. 13(1): 346. 1852. \\
\hline Solanum appendiculatum Dunal & Solan. Syn. 5. 1816. \\
\hline Solanum bicorne Dunal & in DC., Prodr. 13(1): 232. 1852. \\
\hline Solanum bicorne Dunal var. angustifolium Dunal & in DC., Prodr. 13(1): 233. 1852. \\
\hline Solanum bulbocastanum Dunal & in Poir., Encycl. Suppl. 3: 749. 1814. \\
\hline Solanum californicum Dunal & in DC., Prodr. 13(1): 86. 1852. \\
\hline Solanum calycinum Dunal & in Poir., Encycl. Suppl. 3: 747. 1814. \\
\hline Solanum campylocladum Dunal & in DC., Prodr. 13(1): 173. 1852. \\
\hline Solanum dulcamaroides Dunal & in Poir., Encycl. Suppl. 3: 751. 1814. \\
\hline Solanum enoplocalyx Dunal & in DC., Prodr. 13(1): 222.1852. \\
\hline Solanum ensifolium Dunal & in DC., Prodr. 13(1): 186. 1852. \\
\hline Solanum hernandesii Dunal & in Poir., Encycl. Suppl. 3: 771. 1814. \\
\hline Solanum lentum Jacq. var. echinatum Dunal & in DC., Prodr. 13(1): 173. 1852. \\
\hline Solanum leptanthum Dunal & in Poir., Encycl. Suppl. 3: 747. 1814. \\
\hline Solanum luridum Dunal & in DC., Prodr. 13(1): 113. 1852. \\
\hline Solanum mexicanum Dunal & in Poir., Encycl. Suppl. 3: 770. 1814. \\
\hline Solanum mocinianum Dunal & in Poir., Encycl. Suppl. 3: 757. 1814. \\
\hline Solanum mocinianum Dunal var. Iuteiflorum Dunal & in DC., Prodr. 13(1): 164. 1852. \\
\hline Solanum multinervium Dunal & in DC., Prodr. 13(1): 127. 1852. \\
\hline Solanum pavonii Dunal & in DC., Prodr. 13(1): 226. 1852. \\
\hline Solanum porphyranthum Dunal & in DC., Prodr. 13(1): 244. 1852. \\
\hline Solanum pyriforme Dunal var. uniflorum Dunal & in DC., Prodr. 13(1): 369. 1852. \\
\hline Solanum rudepannum Dunal & in DC., Prodr. 13(1): 264. 1852. \\
\hline Solanum symphysicaulis Dunal & in DC., Prodr. 13(1): 106. 1852. \\
\hline Solanum tricolor Dunal & in Poir., Encycl. Suppl. 3: 756. 1814. \\
\hline Solanum tridynamum Dunal & in Poir., Encycl. Suppl. 3: 776. 1814. \\
\hline Solanum tridynamum Dunal var. stylosum Dunal & in DC., Prodr. 13(1): 334. 1852. \\
\hline Solanum ulmoides Dunal & in DC., Prodr. 13(1): 130. 1852. \\
\hline
\end{tabular}


these negatives are widely distributed in herbaria around the world, and so I have here cited the F negative number in addition to the MA barcode for each specimen cited in the text where it is cited for the first time. Some duplicates of these specimens were retained at F, but I have not comprehensively assessed the holdings there for isotype material.

In Solanum, 22 new names were coined in the Sessé and Mociño publications. Sessé and Mociño also used many Linnaean (and other) names, some of which were subsequently wrongly attributed to them in Index Kewensis (and from that, into the International Plant Names Index, IPNI, http://ipni.org). In the Plantae Novae Hispaniae Sessé and Mociño give literature attributions (e.g., to Linnaeus's Hortus Cliffortianus (1738) as "Hort. Cliff." or their own Flora Mexicana as "Fl. Mex.") to Solanum species when they used another author's concept, but this is not always the case. Thus, deciding if Sessé and Mociño were intending to coin a new name can sometimes be difficult, but McVaugh (2000a) provides clear advice on identification of names used in their previously published (usually Linnaean) sense. In both works, Sessé and Mociño often copied the Linnaean diagnosis almost exactly, and usually cited in the distribution the Linnaean distribution in addition to their own. In some cases (see Solanum dipbyllum and Solanum scandens below) the situation is more complicated. It must be remembered that the principle of priority was not firmly established at the time Sessé and Mociño were working (see Knapp et al., 2004b), and that re-use of epithets was common (Linnaeus himself even did it, see Jarvis, 2007). Species included by Sessé and Mociño identified as species already described are listed in McVaugh (2000a) in the format "Solanum aethiopicum (L.) sensu Sessé \& Mociño"; I have generally not considered any of these as intentional new namings by Sessé and Mociño (but see Solanum diphyllum and S. scandens below).

Ten of the new Solanum names in Flora Mexicana and Plantae Novae Hispaniae have no herbarium material specifically associated with them at MA or in any other of the herbaria where the Sessé and Mociño duplicates ended up (McVaugh, 2000a). All of these names are from the more preliminary, note-like (McVaugh, 2000a) Flora Mexicana. These names are included here, with an indication of their possible identity, but I feel in most cases it will be more appropriate to either neotypify them with modern specimens in Mexican herbaria from the Sessé and Mociño's type localities (as I have done for two names here) or propose them for rejection under the provisions of the International Code for Botanical Nomenclature (McNeill et al., 2006), thus removing a potentially destabilising influence. Several of these taxa are under cur- rent study by members of the PBI Solanum group, so decisions about their status will be taken in a monographic context. I neotypify two of these names here as part of a monographic study on the Dulcamaroid clade (sensu Bohs, 2005).

McVaugh suggested that the typification of Sessé and Mociño's names from herbarium material alone was dangerous and uncertain ("difficult and ordinarily impossible”, McVaugh, 2000a: 28), but it is important to fix their usage; this is best done by consulting the printed works in conjunction with the specimens and drawings. Understandable confusion as to the identities of these specimens at the time of editing and publication of Sessé and Mociño's works has meant that labelling of specimens is not always clear, and decisions as to types must be made on practical criteria. As will be seen below, ascertaining the identity of a name is often impossible or very difficult due to the absence of specimens or illustrations. Specimens are preferable to illustrations in typifying solanums, as so often key characteristics of species are microscopic details of pubescence or flower parts. I therefore feel that lectotypes or neotypes must be sought in Sessé and Mociño's herbarium wherever possible, and I have here typified all Solanum names that are represented by identifiable specimens in the Sessé and Mociño herbarium at MA, except two, which I have neotypified with specimens from MEXU. Because the labels on the specimens sometimes do not correspond exactly with the protologue, either in name or description, some of the names are neotypified, rather than lectoypified, here (see Article 9.6, Recommendation 9B1 of the ICBN, McNeill et al., 2006).

\section{Taxonomic treatment and typifications}

Solanum ayacuyense Sessé \& Moc., Fl. Mex. ed. 2: 52. 1894

Ind. loc.: "Habitat in Acayucae circuitibus" [México: Veracruz, Acayucan, 17 $\left.56^{\circ} \mathrm{S}, 94^{\circ} 55^{\prime} \mathrm{W}\right]$.

Type material not located, no specimens at MA.

Current accepted name: of uncertain status, incertae sedis.

This plant is described as an erect glabrous herb, reddish woolly, with entire lanceolate leaves that are scabrous above and woolly beneath, and terminal, dichotomous panicles with nodding sordid white flowers. The type locality Acayucan, is in southern Veracruz. This plant could be Solanum umbellatum Miller (see S. lanceifolium below) or S. scblechtendalianum Walp., both of which occur in the type locality (M. Nee, pers. comm.). Specimens of these taxa from the type locality should be sought in Mexican herbaria in order to select a neotype. 
Solanum bifidum Sessé \& Moc., Fl. Mex. ed. 2: 51. 1894

Ind. loc.: "Habitat in aridis agris San Martini de Tesmelucan" [México: Puebla, San Martín Texmelucan, $\left.19^{\circ} 17^{\prime} \mathrm{N}, 98^{\circ} 26^{\prime} \mathrm{W}\right]$.

Neotype (designated here), MA 604639 (F neg. 48313, Fig. 1 A); isotype, MA 604640 (F neg. 48312).

Current accepted name: Solanum lanceolatum Cav.

A series of sheets at MA correspond to the description of S. bifidum (MA 604604 (F neg. 48308), MA 604605 (F neg. 48307), MA 604637 (F neg. 48310), MA 604638 (F neg. 48311), MA 604639 (Fig. 1 A), MA 604640). Annotation labels affixed to the sheets MA 604604 and MA 604605 by the Solanum expert C.V. Morton in 1962, suggest that these two sheets are type material of $S$. bifidum, but he never published this decision. I disagree with this assessment. Of the material matching the original description, these two sheets lack the key character of cauline prickles (spines). The original description mentions that the midrib is prickly beneath "costaque inferiore aculeata" and that the prickles are tomentose "Aculei tomentosi, demto apice glaberrimo", and MA 604639 (labelled "S. incanum N", see Fig. 1 A) is the sheet that best matches that character, with prickles tomentose except at the apex and prickles all along the midrib of the leaf undersides. MA 604640 (also labelled "S. cinereum") appears to be from the same gathering as the neotype, as it is morphologically very similar with prickly stems. Of the other sheets that correspond to the description MA 604637 and MA 604638 bear labels with no species designation, and MA 604604 and MA 604605 are labelled "S. incanum $\mathrm{N}$ " with the word "incanum" overwritten by the word "canescens" in a slightly different type of ink. These latter two sheets appear to be from the same gathering, with narrow leaves and unarmed stems.

Solanum cordovense Sessé \& Moc., Fl. Mex. ed. 2: 51. 1894

Ind. loc.: "Habitat in Cordovae montibus" [México: Veracruz, Córdoba, $\left.18^{\circ} 53^{\prime} \mathrm{N}, 96^{\circ} 55^{\prime} \mathrm{W}\right]$.

Neotype (designated here), MA 604616 (F neg. 48315, Fig. 1 B); isotype, MA 604615 (F neg. 48316).

Current accepted name: Solanum cordovense Sessé \& Moc.

Both sheets (MA 604616 (Fig. 1 B), MA 604615) of plants corresponding to the description of $S$. cordovense at MA bear original labels naming them as " $\mathrm{S}$. luridum N", and appear to be from the same plant although they have different "numbers" (see McVaugh, 2000a for the significance of the numbers on the original labels, they do not correspond to collecting numbers as we use them today). This material is a good match for the type material of S. luridum Dunal at G, which was labelled by Pavón as "S[olanum] luridum M[exi]co" (McVaugh, 2000a). McVaugh (2000a) wondered why Nee (1993) treated S. cordovense (1894) as a valid name with $S$. luridum (1852) in synonymy, but $S$. luridum Salisb. (a synonym of $S$. lycopersicum L.) pre-dates Dunal's use of the name. No modern collections from this area were recorded by Nee (1993), but he expected it there in appropriate habitats.

Solanum declinatum Sessé \& Moc., Fl. Mex. ed. 2: 54. 1894

Ind. loc.: "Habitat in montibus calidis Teuzitlani" [México: Puebla, Teziutlán, $19^{\circ} 49^{\prime} \mathrm{N}, 97^{\circ} 21^{\prime} \mathrm{W}$ ].

Neotype (designated here), MA 604645 (F neg. 48223, Fig. 1 C); probable isotype, MA 60444 (F neg. 48235).

Current accepted name: Lycianthes lenta (Sw.) Bitter [Nee, 1986].

There are three specimens of Lycianthes lenta at MA. Two of these (MA 604644, MA 604645, the lectotype) have labels with the name "Solanum reclinatum N", while the third and best specimen (MA 604643) is labelled "Solanum decemfidum N" - the published epithet may have been a concatenation of these two herbarium names. These sheets are also syntype material of Solanum lentum Sw. var. echinatum Dunal, another possible misreading of the "reclinatum" of the label. As a lectotype, I have chosen the specimen with flowers labelled "Solanum reclinatum" (MA 604645). This same sheet was cited as "authentic material" by Nee (1986).

Solanum dichotomum Sessé \& Moc., Pl. Nov. Hisp.: 35. 1888 [as "dichothomum"]

Ind. loc.: "Habitat in Mazatlam" [México: Sinaloa, Mazatlán, $\left.23^{\circ} 12^{\prime} \mathrm{N}, 106^{\circ} 25^{\prime} \mathrm{W}\right]$.

Lectotype (designated here), MA 604601 (F neg. 48342, Fig. 1 D); isolectotypes, MA 604599 (F neg. 48341), MA 604600 (F neg. 48339).

Current accepted name: Solanum refractum Hook. \& Arn.

Although Sessé and Mociño cite "Fl. Mex." as the origin of the diagnosis of $S$. dichotomum, no such name nor a plant of this description appears in that work. The sheets at MA that correspond to the description are of two types: 1) a set of stems with large leaves with slightly lobed margins (MA 604599, MA 603600, MA 604601), and 2) two sheets of very young branches with smaller entire leaves that are more densely pubescent both above and below (MA 604602 (F neg. 48340), MA 604603 (not photographed at F)). Of these sheets, MA 604599 and MA 604603 bear no la- 


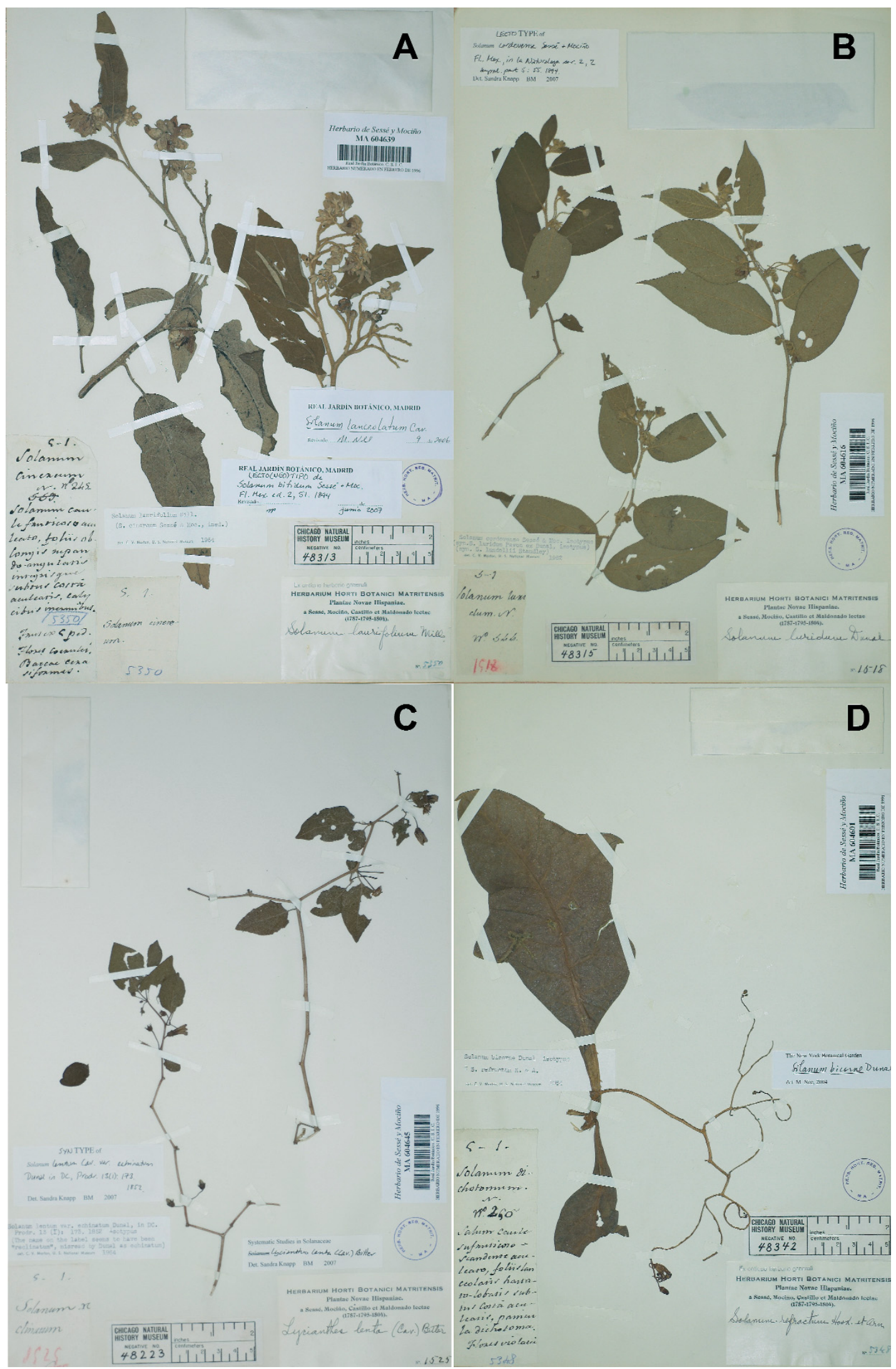

Fig. 1. A, neotype of Solanum bifidum Sessé \& Moc. (=Solanum lanceolatum Cav.) (MA 604639); B, neotype of Solanum cordovense Sessé \& Moc. (MA 604616); C, neotype of Solanum declinatum Sessé \& Moc. (=Lycianthes lenta (Sw.) Bitter) (MA 604645); D, lectotype of Solanum dichotomum Sessé \& Moc. (=Solanum refractum Hook. \& Arn.) (MA 604601). 
bels, MA 604600 has a label in a different (later?) hand of "S. dicomum N", MA 604602 has an original label of "S. dichotomum N" and MA 604601 (see Fig. 1 D) has an extensive label with "S. dichotomum N" and a brief description, but no locality. In 1964, C.V. Morton annotated both MA 604602 and MA 604603 as holotypes of $S$. dichotomum, apparently equating this Sessé and Mociño name with Dunal's (1852) S. bicorne var. angustifolium. I disagree with his assessment of these sheets, and choose here MA 604602 as the lectotype of $S$. dichotomum based on its label that matches the original description more clearly. One minor difference between the label description of this plant and that published is that the label states "flores violacei" while the protologue cites "flores albis". An additional complication is the interpretation of the numbers assigned to the sheets in Chicago (usually on the labels in the lower $\mathrm{R}$ hand corner) that have been interpreted as signifying the duplicate status of some of these sheets. These numbers are not collecting numbers as currently used, and should not be interpreted as such (McVaugh, 2000a); the five sheets at MA have 3 different "numbers", but are morphologically of two gatherings. I have chosen to ignore these "numbers" in assessing the type status of these sheets. Solanum bicorne and its variety angustifolium were described from material said to be from "Nueva España Herb. Pavón" and the holotype of $S$. bicorne is labelled as "S. bicorne" in Pavón's hand (F neg. 34109). Clark \& al. (in litt.) have not differentiated type material of these two taxa at MA, but have put the names in synonymy. I suggest material of the smaller-leaved taxon in MA represents isotype material of var. angustifolium, while the larger leaved material is isotype material of S. bicorne.

Solanum diphyllum Sessé \& Moc., Fl. Mex. ed. 2: 50. 1894, nom. illeg., non L., 1753

Ind. loc.: "Habitat in Cordovae" [México: Veracruz, Córdoba, $\left.18^{\circ} 53^{\prime} \mathrm{N}, 96^{\circ} 55^{\prime} \mathrm{W}\right]$.

Lectotype (designated here), MA 604656 (F neg. 48330, Fig. 2 A).

Current accepted name: Solanum nudum Dunal.

Sessé and Mociño's use of the name $S$. diphyllum is very complicated, and is confounded by the publication of the Plantae Novae Hispaniae before the Flora Mexicana (see above and McVaugh, 2000a). In the Plantae Novae Hispaniae, they cited "Fl. Mex.", implying therefore that they were using the name in the sense of that manuscript, and cited "Quahunahuacae" (near Cuernavaca in Morelos state, McVaugh, 2000a) as the locality, and in synonymy cite a description and reference to "Hort. Cliff. 61" of Linnaeus. Whether this addition was inserted by the editors of the Plantae Novae Hispaniae is unclear. In Flora Mex- icana, on page 50, "S. diphyllum" is said to come from "Cordovae", and on page 53, a species named "S. diphyllum?" is said to come from "Tuxtlae ac Ahualulci sylvis". Since they cited "Fl. Mex." in the earliest description of S. diphyllum, but only cited Linnaeus's earlier S. diphyllum in apparent synonymy, I am assuming they were intending this as a new name. Other taxa used in a Linnaean or other sense in Plantae Novae Hispaniae are accompanied by exact literature references associated with the diagnosis such as "Hort. Cliff. 60" (for S. tuberosum), "Suppl. p. 147" (for S. scandens, see below) or "Jacq., Amer. 49, t.35" (for S. havanense). Also, since they cite "Fl. Mex." for S. diphyllum in the work published in 1888, I am assuming that despite the different localities, they equated these taxa. Therefore, I consider that the name $S$. diphyllum used by Sessé and Mociño in their manuscript of Flora Mexicana was intended as new, and that a type is needed for the 1894 concept of this taxon, despite its being published after the more polished version of the treatment, where Linnaeus's name was cited in synonymy. Specimens identified as S. diphyllum in the Sessé and Mociño herbarium at MA are a mixture of three very similar taxa in Solanum section Geminata (sensu Knapp, 2002): S. aphyodendron S. Knapp, S. dipbyllum L. and S. nudum Dunal. Only two specimens have authentic labels of "S. diphyllum" (MA 604656 (Fig. 2 A), MA 604654 (F neg. 48289)) and both are plants of $S$. nudum Dunal, while MA 604655 (F neg. 48286) has a label in a different, later hand, and is a mixture of $S$. nudum and $S$. dipbyllum L. An additional three sheets (MA 604657 [F neg. 48285, also with an original label of "S. repandum N", a name that appears nowhere in the published works], MA 604658 (F neg. 48288), MA 604659 (F neg. 48287)) are labelled "Solanum diphyllum L.” by Paul C. Standley (see McVaugh, 2000a), and another (MA 604660 (F neg. 48331)) is labelled "Solanum nudum HBK" in Standley's hand. All of these, except MA 604657 which is S. aphyodendron, are $S$. nudum. In order to stabilise the concept of $S$. diphyllum Sessé \& Moc., I have selected the specimen (Fig. 1 D) with both flowers and fruits and a label with the name "S. diphyllum" the lectotype of this name.

Solanum lanceifolium Sessé \& Moc., Fl. Mex. ed. 2: 51. 1894 [as "lancifolium"], nom. illeg., non Jacq., 1789.

Ind. loc.: "Habitat juxta Orizavam" [México: Veracruz, Orizaba, $\left.18^{\circ} 51^{\prime} \mathrm{N}, 97^{\circ} 06^{\prime} \mathrm{W}\right]$.

Neotype (designated here), MA 604635 (F neg. 48352, Fig. 2 B); isotype, MA 604634 (F neg. 48353).

Current accepted name: Solanum umbellatum Miller. 


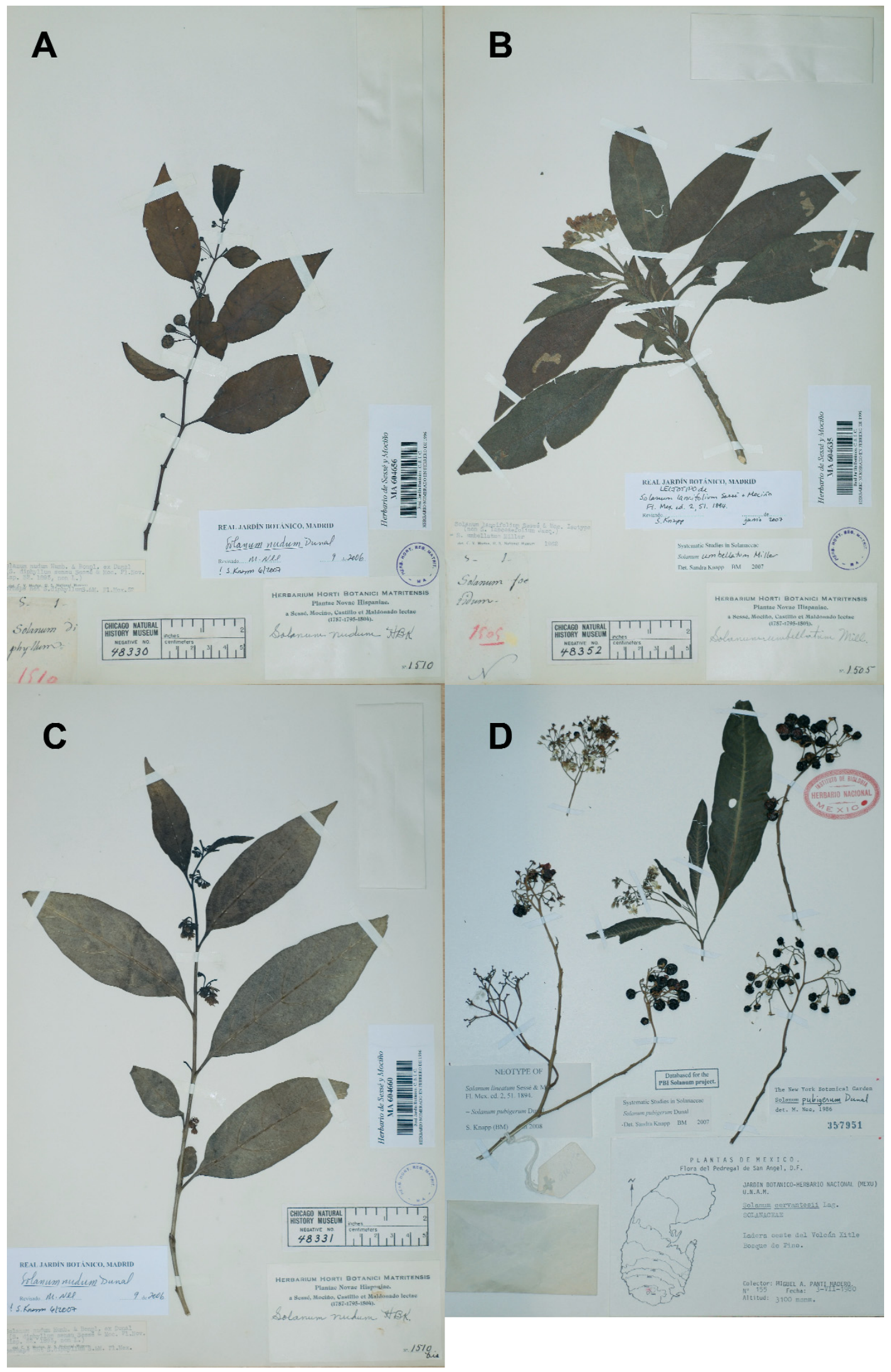

Fig. 2. A, lectotype of Solanum diphyllum Sessé \& Moc. (=Solanum nudum Dunal) (MA 604656); B, lectotype of Solanum lanceifolium Sessé \& Moc. (=Solanum umbellatum Miller) (MA 604635); C, neotype of Solanum lanceolatum Sessé \& Moc. (=Solanum nudum Dunal) (MA 604660); D, neotype of Solanum lineatum Sessé \& Moc. (= Solanum pubigerum Dunal) (Panti-Madero 155, MEXU). 
No sheet in the Sessé and Mociño herbarium at MA is labelled "S. lancifolium", but the specimens selected as neotypes here correspond well with the description of a tomentose shrub with terminal dichotomous inflorescences and lanceolate, entire leaves with thin, erect, stellate trichomes. Specifically, S. lanceifolium was stated to have a strong odor: "Proprietas. Tota planta foetidissimo et narcotico odore pollet". C.V. Morton suggested in annotation labels dated 1962 that the two sheets selected here were potential type material of $S$. lanceifolium, despite their not being named as such on the sheets. Both these sheets are $S$. umbellatum, an unarmed plant with a strong foetid, almost narcotic odor, both are labelled "S. foetidum N", and neither has any descriptive element to the label. I have chosen the better of these two sheets as the neotype (MA 604635, Fig. 2 B), and the other sheet (MA 604634) as an isotype as it is so similar that I feel it is likely to have come from the same gathering.

Solanum lanceolatum Sessé \& Moc., Fl. Mex. ed. 2: 53. 1894, nom. illeg., non Cav., 1795

Ind. loc.: "Habitat et floret cum praecedente"; "Habitat in Tuxtlae confinis" [México: Veracruz, Santiago Tuxtla, $18^{\circ} 28^{\prime} \mathrm{N}, 95^{\circ} 18^{\prime} \mathrm{W}$, alt. $195 \mathrm{~m}$, or San Andrés Tuxtla, $\left.18^{\circ} 27^{\prime} \mathrm{N}, 95^{\circ} 13^{\prime} \mathrm{W}\right]$.

Neotype (designated here), MA 604660 (F neg. 48331, Fig. 2 C).

Current accepted name: Solanum nudum Dunal.

The description is of a glabrous shrubby plant with lanceolate, entire leaves and lateral umbellate inflorescences with about 5 flowers. McVaugh (2000a) suggests this could be $S$. diphyllum L. or one of its relatives in section Geminata, all of which are glabrous shrubs with lateral leaf-opposed inflorescences and simple, entire leaves. Differentiating which species of the group this name represents is difficult without specimens; these plants are all remarkably similar and difficult to distinguish (see Knapp, 2002). This name could potentially refer to $S$. nudum Dunal, $S$. dipbyllum L. or S. apbyodendron $\mathrm{S}$. Knapp, all of which are common in the area of the type locality. In order to fix the usage of this name I have chosen to lectotypify it using one of the several sheets of these species that matches the description in having relatively narrow leaves and few-flowered inflorescences (Fig. 2 C; MA 604660). This sheet is unlabelled except by later botanists. See $S$. diphyllum above for a discussion of mixed collections of these three very similar species in the Sessé and Mociño herbarium.

Solanum lineatum Sessé \& Moc., Fl. Mex. ed. 2: 51. 1894, nom. illeg., non Ruiz \& Pav., 1799

Ind. loc.: "Habitat in Sancti Angeli circuitibus alisque frigidis Nov. Hisp. locis" [México: Distrito Fe- deral, pedregal de San Ángel, ca. $19^{\circ} 20^{\prime} \mathrm{N}, 99^{\circ} 11^{\prime} \mathrm{W}$, or surrounding mountains].

Neotype (designated here), México. Distrito Federal: pedregal de San Ángel, oeste de volcán Xitle, M.A. Panti Madero 155 (MEXU, Fig. 2 D).

Current accepted name: Solanum pubigerum Dunal.

Sessé and Mociño (1894) used the epithet "lineatum" twice in Flora Mexicana for two different plants from different localities (see below for the second $S$. lineatum), making these two names homonyms with equal priority (Article 53.6, McNeill \& al., 2006). Both, however, are illegimate as they are homonyms of S. lineatum Ruiz \& Pav. The description of this plant as an unarmed shrub with entire lanceolate glabrous leaves and supraxillary dichotomous inflorescences with middle-sized ("mediocres") white flowers and black fruit the size a cherry suggests Solanum pubigerum Dunal or S. aligerum Schldl., both relatively common throughout montane central Mexico. Plate 6331.0673 in the Torner Collection of Sessé and Mociño Biological Illustrations (Hunt Institute for Botanical Documentation) is unlabelled, but represents $S$. pubigerum, and plate 6331.0841, similarly unlabelled, is probably $S$. aligerum Schltdl., a very similar species with larger flowers. Although Sessé and Mociño may have collected both species, $S$. pubigerum is far more common in the area of Mexico City (where both type localities are) and I have seen no material of $S$. aligerum from the type locality. I am therefore neotypifying $S$. lineatum with a modern specimen of S. pubigerum (Panti Madero 155, MEXU; see Fig. 2 D) from the Pedregal de San Ángel in the valley mountains around Mexico City, and also recognising S. lineatum from page 53 as the same species (see below).

Solanum lineatum Sessé \& Moc., Fl. Mex. ed. 2: 53. 1894, nom. illeg., non Ruiz \& Pav., 1799

Ind. loc.: "Habitat in oppido S. Augustini prope Mexicum" [México: Distrito Federal, Tlalpan (San Agustín), $\left.19^{\circ} 17^{\prime} \mathrm{N}, 99^{\circ} 10^{\prime} \mathrm{W}\right]$.

Neotype (designated here), México. Distrito Federal: municipio Tlalpan, cerca de Xitle, N. Herrera C. 129 (MEXU, Fig. 3 A).

Current accepted name: Solanum pubigerum Dunal.

The description of this plant is slightly different to that of the $S$. lineatum described on page 51 (see above); it is said to be an unarmed shrub with entire lanceolate leaves and dichotomous inflorescences opposite the leaves at the tips of the stems composed of 5 -flowered umbels with small white flowers and black fruit the size of that of Solanum nigrum L. This match- 

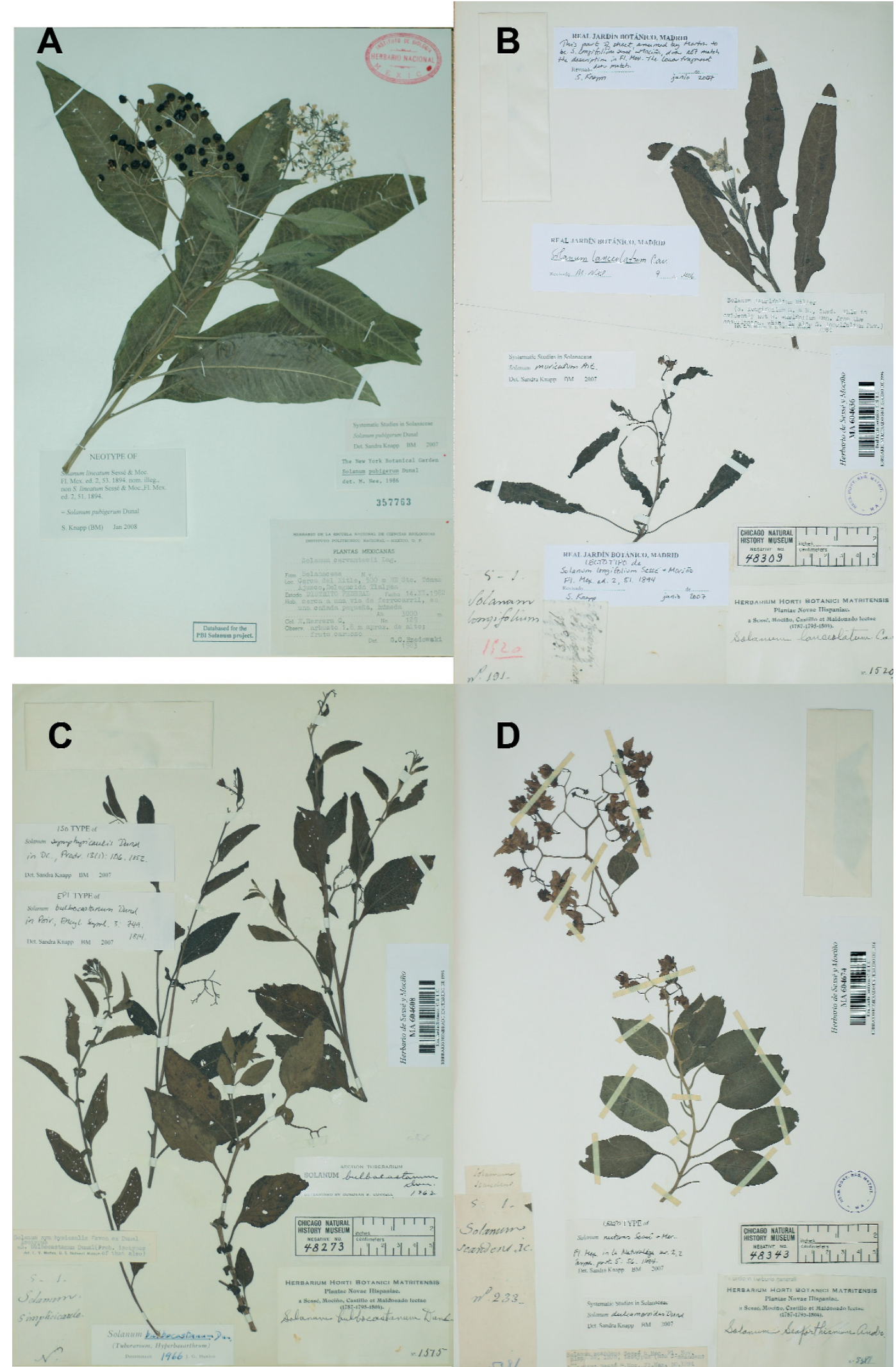

Fig. 3. A, neotype of Solanum lineatum Sessé \& Moc. (=Solanum pubigerum Dunal) (Herrera C. 129, MEXU); B, lectotype of Solanum longifolium Sessé \& Moc. (=Solanum muricatum Aiton) (MA 206020, lower left hand fragment); C, epitype of Solanum mexicanum Sessé \& Moc. (=Solanum bulbocastanum Dunal) (MA 604608); D, neotype of Solanum nutans Sessé \& Moc. (=Solanum dulcamaroides Dunal) (MA 604674). 
es the description of Solanum pubigerum Dunal, common in the Mexico City area and throughout montane central Mexico, which has smaller fruit and more clustered flowers than the very similar S. aligerum. Plate 6331.0673 in the Torner Collection of Sessé and Mociño Biological Illustrations (Hunt Institute for Botanical Documentation) is unlabelled, but represents $S$. pubigerum, and plate 6331.0841, similarly unlabelled, is probably $S$. aligerum Schltdl., a very similar species with larger flowers. I have chosen a modern collection from near the type locality in the district of Tlalpan in Mexico City (Herrera C. 129, MEXU, see Fig. 3 A) with which to typify this species. Although Sessé and Mociño might have collected both $S$. aligerum and $S$. pubigerum, the latter is far more common in both localities cited for $S$. lineatum (page 51 and 53).

Solanum longifolium Sessé \& Moc., Fl. Mex. ed. 2: 51. 1894, nom. illeg., non Vahl, 1797

Ind. loc.: "Habitat in Mexici hortis, vulgo Melon de China" [no specific locality].

Lectotype (designated here), MA 604636, lower small specimen (F neg. 48309, Fig. 3 B).

Current accepted name: Solanum muricatum Ait.

Material under the name of "S. longifolium" in the Sessé and Mociño herbarium is referable to at least three species, none of which McVaugh (2000a) considered to match the description. He appears not to have noticed the difference between the small fragment mounted at the bottom of MA 604636 (Fig. 3 B), and the larger stem on the same sheet. C.V. Morton equated S. longifolium (annotation label in 1962) with S. laurifolium Miller (=S. lanceolatum Cav.) but also appears not to have recognised the fragment in the lower part of the sheet as different. The larger stem on MA 604636 is indeed S. lanceolatum Cav., but the smaller fragment is $S$. muricatum Ait., the pepino, and exactly corresponds to the description in Flora Mexicana. The description of $S$. longifolium is of a herb with linear leaves and a fruit the size of an apple, fragrant, acid and slightly sweet. Although there is no fruit on the specimen, the stem fragment is of $S$. muricatum, which has apple-sized, fragrant fruits that are highly esteemed in the Andes. It is interesting that the common name for this plant was "Melón de China" as it is a native of the Andes, not of the Old World. A poor specimen that is a possible isotype is at $\mathrm{F}$ ( $\mathrm{F}$ 845045). Further confusion over the name S. longifolium in the Sessé and Mociño collections is caused by a specimen sold by Pavón to de Candolle in Geneva. McVaugh (2000a) mentions that the holotype of $S$. ensifolium Dunal in $\mathrm{G}$ is labelled " $\mathrm{S}$. longifolium $\mathrm{Nv}^{\circ}$. Rubias", but that sheet is of an armed plant armed with prominent prickles on stems and leaves. The duplicate of that collection in MA (MA 604619, F neg. 48338 ) is labelled "S. igneum ... N V ${ }^{\circ}$. Rubias" and is a specimen of the Puerto Rican endemic $S$. $d r y$ mophilum O.E. Schulz, for which S. ensifolium is the older name.

Solanum mexicanum Sessé \& Moc., Pl. Nov. Hisp.: 35. 1888, nom. illeg., non Dunal, 1814

Ind. loc.: "Habitat in Tepetlpao montibus prope Sancti Angeli oppidum" [México; Distrito Federal, Monte Terepa [Tepelpa], near San Ángel].

Lectotype (designated by Spooner \& al., 2004), plate 6331.0261 in the Torner Collection of Sessé and Mociño Biological Illustrations, Hunt Institute for Botanical Documentation (incorrectly cited as 0621 in Spooner \& al., 2004); isotype, Dunal, unpubl. Tab. 31, at MPU; epitype (designated here) MA 604608 (F neg. 48273, Fig. 3 C).

Current accepted name: Solanum bulbocastanum Dunal.

Spooner \& al. (2004) lectotypified S. mexicanum with the Torner Collection plate 6331.0261 (labelled "Solanum mexicanum N", see Plate 7 in Spooner \& al., 2004) of $S$. bulbocastanum that is also the type of that name, thus making the epithets homotypic. They (Spooner \& al., 2004) inadvertently transposed digits in the citation of the Torner Collection plate number, citing it as 0621, but the correct Torner Collection accession number is 6331.0261. Dunal clearly saw the Sessé and Mociño drawing when Mociño brought them to Montpellier, and the resident artist, Toussaint-François Node Veran, made a very accurate copy, today held at the herbarium in Montpellier (MPU). This drawing has been designated an isotype by Spooner \& al. (2004). Two specimens of S. bulbocastanum (MA 604607 (F neg. 48274), MA 604608 (Fig. 3 C) are potential epitypes of both $S$. mexicanum and S. bulbocastanum; they are both labelled "S. simplicicaule N". Dunal (1852) described S. symphysicaulis from a sheet in G from "Pavón" where he seemingly mis-read the epithet "simplicicaule" written by Pavón on the G sheet as "symphysicaule" (see McVaugh, 2000a). The two sheets are isotypes of S. symphysicaulis. I have chose MA 604608 as the epitype because it has several mature stems two of which have flowers.

Solanum miltomate Sessé \& Moc., Fl. Mex. ed. 2: 53. 1894

Ind. loc.: "Habitat in Tuxtlae confinis" [México: Veracruz, Santiago Tuxtla, $18^{\circ} 28^{\prime} \mathrm{N}, 95^{\circ} 18^{\prime} \mathrm{W}$, alt. 195 $\mathrm{m}$, or San Andrés Tuxtla, $\left.18^{\circ} 27^{\prime} \mathrm{N}, 95^{\circ} 13^{\prime} \mathrm{W}\right]$.

Type material not located, no specimens at MA. 
Current accepted name: of uncertain status, incertae sedis.

From the description of this plant as glabrous and shiny with paired leaves and 1-flowered inflorescences and the name of "miltomate", I suspect this may be a species of Physalis, possibly the cultivated Physalis philadelphica Lam. This species is known in Mexico as miltomate or tomatillo (in English as the husk tomato) and is commonly cultivated. The flowers are said to be purple, which does not match Physalis, but this could be a misinterpretation of the dark marks in the throat of most Physalis flowers; neotypification of this name should use material in Mexican herbaria.

Solanum nutans Sessé \& Moc., Fl. Mex. ed. 2: 50. 1894

Ind. loc.: "Habitat in Surinam et urbe Queretaro" [México: Querétero, Querétero, 20³6'N, 100²3' W].

Neotype (designated here), MA 604674 (F neg. 48343, Fig. 3 D).

Current accepted name: Solanum dulcamaroides Dunal.

A footnote in Flora Mexicana (1894: 50) equates this name with $S$. scandens of the Plantae Novae Hispaniae, and the description of $S$. scandens in Plantae Novae Hispaniae is exactly the same as that of $S$. nutans with the exception of a reference to a drawing in the Sesse and Mociño collection in the description of S. nutans ("ic. H.N."). The reference here is to $S$. scandens L., a plant from Surinam described by Linnaeus from material sent by Anders Dahlberg from Surinam, the correct name for which is $S$. uncinellum Lindl., a very different species to that collected in Mexico. The reference to a drawing or painting ("ic. H.N.") may refer to the unlabelled plate 6331.1503 in the Torner Collection of Sessé and Mociño Biological Illustrations (Hunt Institute for Botanical Documentation) which is probably $S$. dulcamaroides, but the plate is not annotated by either de Candolle or Dunal. The name $S$. scandens was used in a different sense in the second edition Flora Mexicana (see below) and another name was introduced for perhaps the same plants ( $S$. sarmentosum, see below), so I consider it necessary to typify all of these names in order to stabilise their usage. No specimens are labelled "S. nutans" in the Sessé and Mociño herbarium at MA, but MA 604674 (Fig. 3 D) is labelled "S. scandens IC." and I am interpreting this as a reference to the citation of a drawing in the diagnosis of $S$. nutans (equated incorrectly with $S$. scandens L.). Another specimen (MA 604676 (F neg. 48318)) labelled "S. scandens IC." has a lengthier label with the locality "Hav". et Queretaro" and a short description, this is of a Cuban plant and is here equated with $S$. scandens Sessé \& Moc. that was published in 1894, not the plant erroneously equated with $S$. scandens L. (see below).

Solanum ocoapense Sessé \& Moc., Fl. Mex. ed. 2: 52. 1894

Ind. loc.: "Habitat in Ahualulci montibus" [México: Tabasco, Ocuapan, $17^{\circ} 51^{\prime} \mathrm{N}, 93^{\circ} 29^{\prime} \mathrm{W}$, or San Luis Potosí, Ahualulco, $\left.22^{\circ} 24^{\prime} \mathrm{N}, 101^{\prime} 10^{\prime \prime} \mathrm{W}\right]$.

Type material not located, no specimens at MA.

Current accepted name: of uncertain status, incertae sedis.

McVaugh (2000a) suggests this species is named for Ocoapan in western Tabasco, but the type locality is cited as Ahualulco, which is in the mountains of San Luis Potosí. Both these areas were visited by members of the expedition, and I think it is more likely that the plant comes from the latter as no Solanum species in coastal Tabasco have the combination of characters in the description. The plant is described as spiny, with lobed leaves and small cauline prickles, and purple, nodding flowers. This sounds like a member of Solanum section Torva (see Nee, 1999), of which $S$. lanceolatum Cav. is the one of the few purple-flowered taxa occurring in the mountains of San Luis Potosí (Nee, pers. comm.).

Solanum sarmentosum Sessé \& Moc., Fl. Mex. ed. 2: 51.1894

Ind. loc.: "Habitat in Queretari et Temescaltepec hortis" [México: Querétero, Querétero, $20^{\circ} 36^{\prime} \mathrm{N}$, $100^{\circ} 23^{\prime} \mathrm{W}$ and México, Temascaltepec, $19^{\circ} 02^{\prime} \mathrm{N}$, $\left.100^{\circ} 03^{\prime} \mathrm{W}\right]$

Lectotype (designated here), MA 604621 (F neg. 48321, Fig. 4A); isolectotype, MA 604620 (F neg. 48319).

Current accepted name: Solanum dulcamaroides Dunal.

Both S. sarmentosum and S. nutans from Flora Mexicana cite Queretaro as one locality, suggesting confusion over the naming these two taxa in Sessé and Mociño's manuscripts. As stated above (see $S$. nutans), I consider it helpful to lectotypify all the names associated with this set of specimens in order to stabilise usage and synonymy. Two specimens in the Sessé and Mociño herbarium at MA bear original labels of "S. sarmentosum N" [MA 604621 (Fig. 4 A), MA 604624 (F neg. 48317)]. MA 604621 also has a reference to a drawing, as does the protologue; neither of these sheets cites a locality. An additional unlabelled specimen (MA 604620) is morphologically very similar to MA 604621 and I suggest these come for the same gathering and should be treated as duplicates. The 


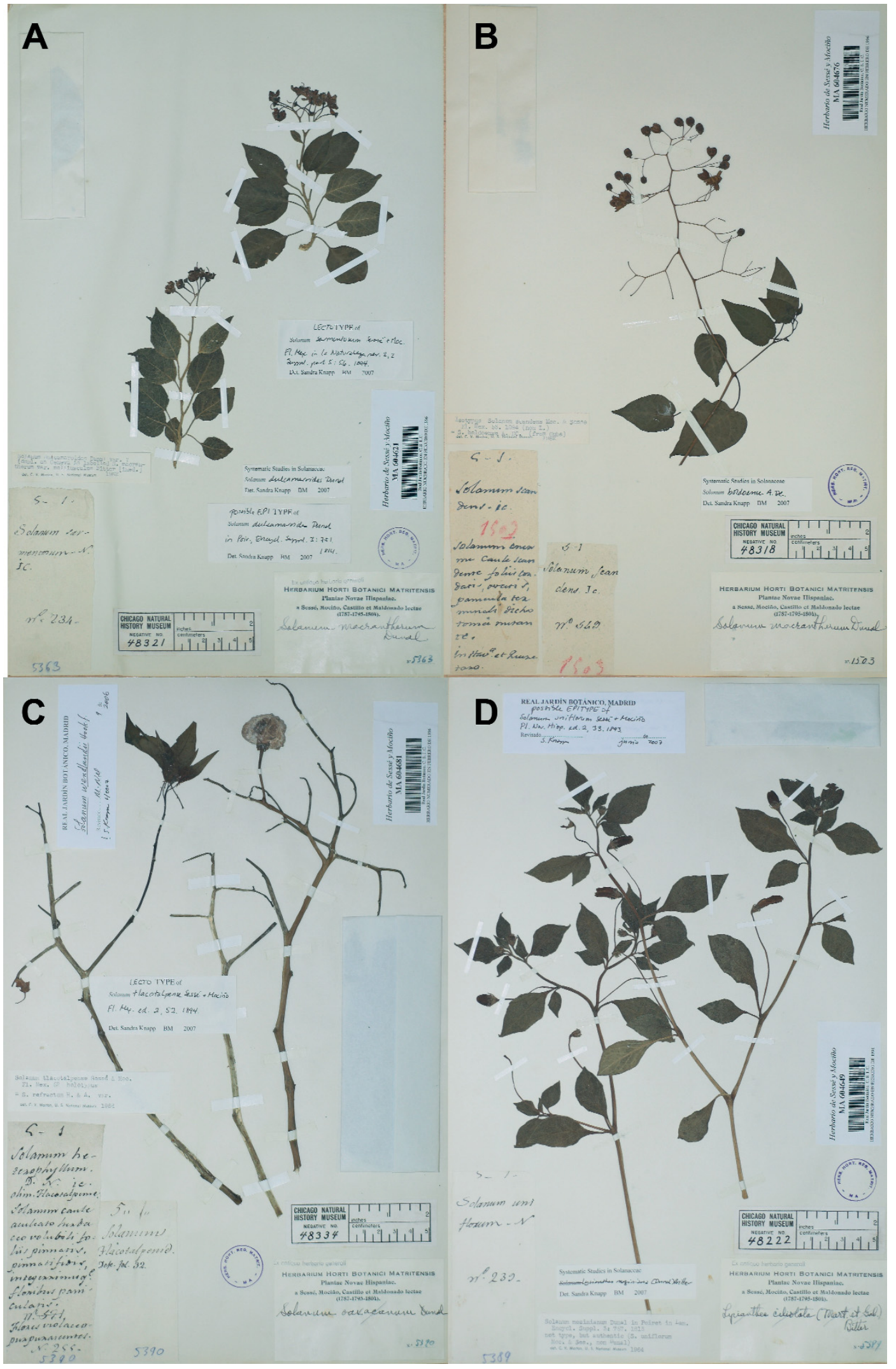

Fig. 4. A, lectotype of Solanum sarmentosum Sessé \& Moc. (=Solanum dulcamaroides Dunal) (MA 604621); B, lectotype of Solanum scandens Sessé \& Moc. (=Solanum boldoense Dunal \& A DC.) (MA 604676); C, lectotype of Solanum tlacopalense Sessé \& Moc. (=Solanum wendlandii Hook. f.) (MA 604681); D, epitype of Solanum uniflorum Sessé \& Moc. (=Lycianthes mocinianum (Dunal) Bitter) (MA 604649). 
neotype designated for $S$. nutans above may also be form the same gathering as these two specimens, and all these collections are potential epitype material for S. dulcamaroides, which is based on one of the Sessé and Mociño drawings seen by Dunal in Montpellier (probably Troner collection 6331.1503, but the painting is not annotated by Dunal or de Candolle, see above).

Solanum scandens Sessé \& Moc., Fl. Mex. ed. 2: 53. 1894

Ind. loc.: "Habitat in Havanae hortis; vulgo Jazmin de Italia apellatur" [Cuba: La Habana, $23^{\circ} 07^{\prime} \mathrm{N}$, $\left.82^{\circ} 21^{\prime} \mathrm{W}\right]$.

Lectotype (designated here), MA 604676 (F neg. 48318, Fig. 4 B); isolectotype MA 604675 (not photographed at F).

Current accepted name: Solanum boldoense Dunal $\&$ A. DC.

Considerable confusion exists over the use of the epithet "scandens" in Sessé and Mociño's works (see above), but it is clear that on page 53 of Flora Mexicana, they were using $S$. scandens in the sense of a new name, different from that of Linnaeus, which they renamed $S$. nutans (see above and $S$. sarmentosum). The specimen (MA 604676, Fig. 4 B) labelled "S.scandens IC." in the Sessé and Mociño herbarium at MA with the locality "Hav". et Queretaro" demonstrates the confusion over the identity of all these plants. MA 604676 (the lectotype) is a specimen of the Cuban endemic $S$. boldoense Dunal \& A.DC., suggesting [confirming?] the localities were added to the labels after the fact. Another sheet of the same plant, MA 604675, appears to be from the same gathering, and I have designated it here as an isotype. The "IC." referred to on the label may be plate 6331.1503 of the Torner Collection, whose identity must be confirmed (see above).

Solanum tabascense Sessé \& Moc., Fl. Mex. ed. 2: 52. 1894

Ind. loc.: "Habitat in Ahualulci sylvis" [México: Tabasco, sin. loc. or San Luis Potosí, Ahualulco, $\left.22^{\circ} 24^{\prime} \mathrm{N}, 101^{\prime} 10 ” \mathrm{~W}\right]$.

Type material not located, no specimens at MA.

Current accepted name: of uncertain status, incertae sedis.

No locality named Ahualulco exists today in Tabasco, but this plant could be from Ahualulco in San Luis Potosí (see $S$. ocoapense above). This plant is described as a flexuous unarmed shrub with roughened stems, opposite branches and leaves, and simple, short 7-flowered inflorescences with purple flowers. This does not sound like a member of the genus
Solanum, but could be one of the epiphytic Solanaceae such as Merinthopodium neuranthum (Hemsl.) Donn. Sm., many of which have tuberulate stems. That species, however, is not known from Tabasco or San Luis Potosí, but does occur in Chiapas (Knapp \& al., 2005).

Solanum tlacotalpense Sessé \& Moc., Fl. Mex. ed. 2: 52. 1894

Ind. loc.: "Habitat ad fluviorum ad Tuxlentium ripas” [México: Veracruz, Tlacotalpan, $18^{\circ} 37^{\prime} \mathrm{N}$, 95³9’W].

Lectotype (designated here), MA 604681 (F neg. 48334, Fig. 4 C); isolectotypes, MA 604680 (F neg. 48333), MA 604682 (F neg. 48335).

Current accepted name: Solanum wendlandii Hook. f.

The type locality is probably near Tlacotalpan which is ca. $50 \mathrm{~km} \mathrm{NW}$ of San Andrés Tuxtla in Veracruz. Three rather mouldy, leafless specimens of $S$. wendlandii (MA 604680, MA 604681 (Fig. 4 C), MA 604682) in the Sessé and Mociño herbarium at MA are clearly duplicates from the same gathering. MA 604680 bears a label in Pavón's hand of "Capsicum frutescens NE" and a fragment of an additional label; MA 604682 and MA 604681 both are labelled "S. heterophyllum D", but MA 604681 has in addition "N Ic. olim Tlacotalpense" a short description and another label stating "S. tlacotalpense N" written by one person and "Desc. fol. 32" (a reference to the composite drawing held in the Torner Collection 6331.1998, which has a flower and fruit of $S$. wendlandii on the right hand side of the drawing (with a fruit of Theaceae on the left hand side), see http://huntbot.andrew.cmu.edu/HIBD/Departments/Art/Torner) written by another, making it the obvious choice for a lectotype (Fig. 3 C). McVaugh (2000a) assumes that this is the same species characterised but not described in Mociño (1993) and said to be from Nicaragua. Solanum wendlandii is found commonly cultivated throughout Central America and southern Mexico (and in many subtropical and tropical regions of the world), and is indigenous from Veracruz to Panama. The drawing said to be of $S$. wendlandii in the Torner Collection (6331.1471, reproduced in Knapp \& al., 2006) bears no resemblance to any of these collections, and is certainly not $S$. wendlandii, but instead may be the plate used to describe $S$. calycinum Dunal. This plate looks very much like a plant of the African cultivated species $S$. macrocarpon $\mathrm{L}$.

Solanum totonacum Sessé \& Moc., Fl. Mex. ed. 2: 53. 1894

Ind. loc.: "Habitat in calidis Tenampulci montibus" [México: Puebla, Tenampulco, 20¹0’N, 97²4’W]. 
Type material not located, no specimens at MA.

Current accepted name: of uncertain status, incertae sedis.

This plant is described as herbaceous and spiny, with lanceolate, sinuate leaves in pairs with spiny veins and red cherry-like fruits with spiny calyces. This description suggests a member of the Micracantha group (see Levin \& al., 2006; previously section Micracantha Dunal sensu Nee, 1999) which includes S. lanceifolium Jacq. and S. adbaerens Willd. (now known as $S$. volubile Jacq.) in this region. The species in this group are very similar morphologically and are distinguished on the details of pubescence and floral morphology. An exact identification is not possible from Sessé and Mociño's description.

Solanum tuxtlense Sessé \& Moc., Fl. Mex. ed. 2: 52. 1894

Ind. loc.: "Habitat in Tuxtlae suburbis" [México: Veracruz, Santiago Tuxtla, $18^{\circ} 28^{\prime} \mathrm{N}, 95^{\circ} 18^{\prime} \mathrm{W}$, alt. 195 $\mathrm{m}$, or San Andrés Tuxtla, $\left.18^{\circ} 27^{\prime} \mathrm{N}, 95^{\circ} 13^{\prime} \mathrm{W}\right]$.

Type not located, no specimens at MA.

Current accepted name: of uncertain status, incertae sedis.

This plant is described as a fistulose herb with short-petiolate leaves in unequal pairs, ovate, subdentate leaves with short petioles, and axillary solitary purple flowers. The axillary inflorescences suggest a species of Lycianthes, but the subdentate leaves are unusual in Solanum or Lycianthes and may mean this is not a member of either genus, nor even of the Solanaceae. McVaugh (2000a) equates this with the species of the same name in Mociño (1993) from El Salvador, whose identity has not been determined.

Solanum uniflorum Sessé \& Moc., Pl. Nov. Hisp.: 35. 1888, nom. illeg., non Dunal, 1816

Ind. loc.: "Habitat in hortis Sancti Angeli prope Mexicum” [México: Distrito Federal, pedregal de San Ángel, ca. $\left.19^{\circ} 20^{\prime} \mathrm{N}, 99^{\circ} 11^{\prime} \mathrm{W}\right]$.

Lectotype (designated by Dean, 1997: 193), plate 6331.0121 in Torner Collection of Sessé and Mociño Biological Illustrations, Hunt Institute for Botanical Documentation; lectotype, Plate 6331.0025 in the Torner Collection of Sessé and Mociño Biological Illustrations, Hunt Institute for Botanical Documentation; epitype (designated here) MA 604649 (F neg. 48222, Fig. 4 D).

Current accepted name: Lycianthes mociniana (Dunal) Bitter.

Dean (1997) lectotypified S. mocinanum Dunal with the Torner Collection plate (6331.0121), an original watercolour with both flowers and fruits depict- ed; she lectotypified S. uniflorum Sessé \& Moc. with the Torner Collection plate (6331.0025) which appears to be a copy of 6331.0121 with flower only and labelled "Solanum pauciflorum uniflorum". In the Torner Collection there is also another apparent copy of the original (6331.0641), labelled "Solanum pauciflorum N" (see Fig. 1 in Dean, 1997 and http://huntbot.andrew.cmu.edu/HIBD/Departments/Art/Torn er). Specimens labelled with these names ("S. uniflorum N”, MA 604648 (F neg. 48221), MA 604649 (Fig. 4 D); "S. pauciflorum N" MA 604651 (F neg. 48227) in MA are therefore candidates for epitypes of $S$. uniflorum and S. mocinianum. I have chose MA 604649 as the epitype for $S$. uniflorum because it is well-preserved, labelled "Solanum uniflorum" and has several stems with flowers. Another of the specimens of $L y$ cianthes mociniana (MA 604647 (F neg. 48230)) is labelled "Solanum incanum N"; "Del. D. Martin" and is not here designated epitype material, nor is MA 604650 (F neg. 48229) which is labelled only "Solanum". Plate 6331.1911 Torner Collection, which is of two fruits, has a note in same hand as the specimen label stating "Del. D. Martin" stating "fruto del Solano /uniflor", so this sheet may have been the model for this illustration.

Solanum volubile Sessé \& Moc., Fl. Mex. ed. 2: 51. 1894, nom. illeg., non Swartz, 1797

Ind. loc.: "Habitat in calidissimus montibus del Espinal” [México: Veracruz, El Espinal, 20² $16^{\prime} \mathrm{N}$, $\left.97^{\circ} 24^{\prime} \mathrm{W}\right]$.

Type material not located, no specimens at MA.

Current accepted name: of uncertain status, incertae sedis.

The description of this plant as a twiner, with 10toothed calyx suggests it is a species of Lycianthes, but accurate identification in the absence of herbarium material or illustrations is not possible. Several species of Lycianthes of similar description occur in the state of Veracruz (see Nee, 1993), but this taxon sounds most like Lycianthes lenta (Sw.) Bitter. I prefer to let neotypification await monographic or regional study of this complex genus.

\section{Acknowledgements}

Thanks are due to Prof. Santiago Castroviejo and the staff of the Real Jardín Botánico de Madrid for hospitality during my stay in Madrid, I learned so much, and realised I knew so little, about the history of botany in Spain; photographs of the lectotypes were taken by staff of the RJB; my stay in Madrid was funded from the SYNTHESYS Project http://www.synthesys.info/ which is financed by European Community Research Infrastructure Action under the FP6 "Structuring the European Research Area" Programme and the National Science Foundation Planetary Biodiversity Inventory (award DEB-0316614 'PBI Solanum -a worldwide 
treatment' - http:nhm.ac.uk/solanaceaesource). Special thanks are due to Rogers McVaugh, whose detailed, monumental work on the Sessé and Mociño collections has provided the essential base for this, and all, study of these fascinating materials. Comments by anonymous reviewers much improved the manuscript, and M. Nee provided much help in determining collecting localities and other aspects of the collection.

\section{References}

Blanco, P. 2000. Los resultados botánicos: manuscritos y herbario. In: De San Pío, M.P. \& Puig-Samper, M.A. (eds.), El águila y el nopal: la expedición de Sessé y Mociño a Nueva España (17871803), pp. 53-68. Lunwerg Editores S.A., Barcelona.

Blanco, P., Puig-Samper, M.A., Zamudio, G., Valero, M. \& Maldonado, J.L. 2000. Exploración botánica de las Islas de Barlovento: Cuba y Puerto Rico. Siglo XVIII. La obra de Martín de Sessé y José Estévez. Ediciones Doce Calles-CSIC, Aranjuez.

Bohs, L. 2005. Major clades in Solanum based on ndhF sequences. Monographs in Systematic Botany from the Missouri Botanical Garden 104: 27-49.

Castroviejo, S. 1998. Foreword. In: Schultes, R.E. \& Nemry von Thenen de Jaramillo Arango, M.J. (transl.) 1998. The journals of Hipólito Ruiz: Spanish botanist in Peru and Chile 1777-1788, pp. 11-16. Timber Press, Portland, Oregon.

Dean, E. 1997. Lectotypification and synonymy of Solanum mozinianum Dunal and Solanum uniflorum Sessé and Mociño. Brittonia 49: 192-196.

Dunal, M.-F. 1813. Histoire naturelle, médicale et économique des Solanum et des genres qui ont été confundus avec eux. Montpellier.

Dunal, M.-F. 1814. Morelle, Solanum. In: Poiret, J.L.M. (ed.), Encyclopédie méthodique, botánique Suppl. 3, pp. 738-780.

Dunal, M.-F. 1816. Solanorum generumque affinium synopsis. Renaud, Montpellier.

Dunal, M.-F. 1852. Solanaceae. In: De Candolle, A.P. (ed.), Prodromus systematis naturalis regni vegetabilis 13(1), pp. 1-690.

Frodin, D.G. 2004. History and concepts of big plant genera. Taxon 53: $753-776$

Fuertes, M., Martínez, C. \& Puig-Samper, M.A. 1999. José Mariano Mociño. El destino de su obra y las cartas a de Candolle. Espacio, Tiempo y Forma, Ser. IV, Hist. Moderna 12: 443-447.

Jarvis, C. 2007. Order out of chaos: Linnaean plant names and their types. Linnean Society of London and the Natural History Museum, London.

Knapp, S. 2002. Solanum section Geminata. Flora Neotropica 84: 1-405.

Knapp, S., Bohs, L., Nee, M. \& Spooner, D.M. 2004a. Solanaceae: a model for linking genomics and biodiversity. Comparative and Functional Genomics 5: 285-291.

Knapp, S., Lamas, G., Nic Lughadha, E. \& Novarino, G. 2004 b. Stability or stasis in the names of organisms: the evolving Codes of nomenclature. Philosophical Transactions of the Royal Society, series B, Biological Sciences 359: 611-622.

Knapp, S., Short, M.J., Sousa-Peña, M. \& Martínez, M. 2005. A preliminary names list for the Solanaceae of Mesoamerica. In: Keating, R.C., Hollowell, V.C. \& Croat, T.B. (eds.), A Festschrift for William G. D'Arcy: The Legacy of a Taxonomist. Monogr. Syst. Bot. Missouri Bot. Gard., Vol. 104, pp. 71-116.

Knapp, S. \& Davidse, G. 2006. Flora of Guatemala revisited. In: Cano, E.B. (ed.), Biodiversidad de Guatemala Volumen 1, pp. 25-47. Universidad del Valle de Guatemala, Guatemala City.

Knapp, S., Stafford, M.J. \& Martínez, M. 2006. A checklist of the Solanaceae of Guatemala. In: Cano, E.B. (ed.), Biodiversidad de
Guatemala Volumen 1, pp. 259-282. Universidad del Valle de Guatemala, Guatemala City.

Knapp, S. 2007a. The description of Solanum and other Solanaceae collected by Humboldt and Bonpland: a case study of collaboration versus competition in $19^{\text {th }}$ century taxonomy. Botanische Jabrbücher für Systematik, Pflanzengeschichte und Pflanzengeographie 127(2): 117-132.

Knapp, S. 2007b. Lectotypification of Cavanilles' names in Solanum (Solanaceae). Anales del Real Jardín Botánico de Madrid 64: 195-203.

Levin, R.A., Myers, N.R. \& Bohs, L. 2006. Phylogenetic relationships among the "spiny solanums" (Solanum subgenus Leptostemonum, Solanaceae). American Journal of Botany 93: 157169.

Linnaeus, C. 1738. Hortus Cliffortianus. Amsterdam.

Maldonado, J.L. 1997. De California a el Petén: el naturalista Riojano José Longinos Martínez en Nueva España. Instituto de Estudios Riojanos, La Rioja.

Maldonado, J.L. 2006. Flora de Guatemala de José Mociño. Ediciones Doce Calles-CSIC, Aranjuez.

Maldonado, J.L. \& Puig-Samper, M.A. 2000. La aventura ultramarina de Sessé y Mociño, la Real Expedición Botanica a Mueva España. In: De San Pío, M.P. \& Puig-Samper, M.A. (eds.), El águila y el nopal: la expedición de Sessé y Mociño a Nueva España (1787-1803), pp. 36-52. Lunwerg Editores S.A., Barcelona.

McNeill, J., Barrie, F.R., Burdet, H.M., Demoulin, V., Hawksworth, D.L., Marhold, K., Nicolson, D.H., Prado, J., Silva, P.C., Skog, J.E., Weirsema, J.H. \& Turland, N.J. 2006. International Code of Botanical Nomenclature (Vienna Code). Regnum Vegetabile 146. A.R.G. Gantner Verlang KG, Liechtenstein.

McVaugh, R. 1977. Botanical results of the Sessé and Mociño expedition (1787-1803) I. Summary of excursions and travels. Contributions from the University of Michigan Herbarium 11: 97-195.

McVaugh, R. 1982. The lost paintings of the Sessé and Mociño expedition: a newly available resource. Taxon 31: 691-692.

McVaugh, R. 1990. Botanical results of the Sessé and Mociño expedition (1787-1803) IV. The library and the herbarium of the expedition. Contributions from the University of Michigan Herbarium 17: 183-214.

McVaugh, R. 2000a. Botanical results of the Sessé and Mociño expedition (1787-1803) VII. A guide to relevant scientific names of plants. Hunt Institute for Botanical Documentation, Pittsburgh, Pennsylvania.

McVaugh, R. 2000b. Los dibujos de la expedicion. In: De San Pío, M.P. \& Puig-Samper, M.A. (eds.), El águila y el nopal: la expedición de Sessé y Mociño a Nueva España (1787-1803), pp. 105116. Lunwerg Editores S.A., Barcelona.

Mociño. J.M. 1993. Guatimalensis prima flora. Fontqueria 37: 1141.

Nee, M. 1986. Solanaceae I. In: Flora de Veracruz, fasc. 49, pp. 1191. Xalapa, Veracruz, México.

Nee, M. 1993. Solanaceae II. Solanum. In: Flora de Veracruz, fasc. 72, pp. 1-158. Xalapa, Veracruz, México.

Nee. M. 1999. Synopsis of Solanum in the New World. In: Nee, M., Symon, D.E., Lester, R.N. \& Jessop, J.P. (eds.), Solanaceae $I V$, pp. 285-333. Royal Botanic Gardens, Kew.

Rickett, H.W. 1947. The royal botanical expedition to New Spain. Crónica Botanica 11: 1-86.

San Pío, M.P. \& Puig-Samper, M.A. (eds.) 2000. El águila y el nopal: la expedición de Sessé y Mociño a Nueva España (17871803). Lunwerg Editores S.A., Barcelona. 
Sessé y Lacasta, M. \& Mociño, J.M. 1887-1891. Plantae Novae Hispaniae. [Naturaleza (Mexico City) ser. 2, vol. 1], Solanum, pp. 32-34, published in 1888.

Sessé y Lacaste, M. \& Mociño, J.M. 1891-1897. Flora Mexicana. [Naturaleza (Mexico City) ser. 2, vol. 2]. Edition 2 revised and set 1894 from p. 49 onwards has priority over edition 1; Solanum pp. $50-53$ of ed. 2 .

Simpson, L.B. 1938. California in 1792: the expedition of José Longinos Martínez. San Marino, California.

Simpson, L.B. 1962. Journal of José Longinos Martinez. Notes and observations of the naturalist of the botanical expedition in Old and New Califronia and the South Coast, 1791-1792. John Howell Books, Santa Barbara, California.

Spooner, D.M., Van den Berg, R.G., Rodriguez, A., Bamberg, J., Hijmans, R.J. \& Lara Cabrera, S.I. 2004. Wild potatoes
(Solanum section Petota; Solanaceae) of North and Central America. Systematic Botany Monographs 68: 209.

Steele, A. R. 1964. Flowers for the king. The expeditions of Ruiz and Pavón and the flora of Peru. Duke University Press, Durham, North Carolina.

Zamudio, G. 2000. Catálogo de los dibujos de la Real Expedición Botánica a Nueva España del Archivo del Real Jardín Botánico de Madrid. In: De San Pío, M.P. \& Puig-Samper, M.A. (eds.), El águila y el nopal: la expedición de Sessé y Mociño a Nueva España (1787-1803), pp. 117-212. Lunwerg Editores S.A., Barcelona.

Associate Editor: C. Aedo Received: 24-X-2007 Accepted: 4-III-2008 